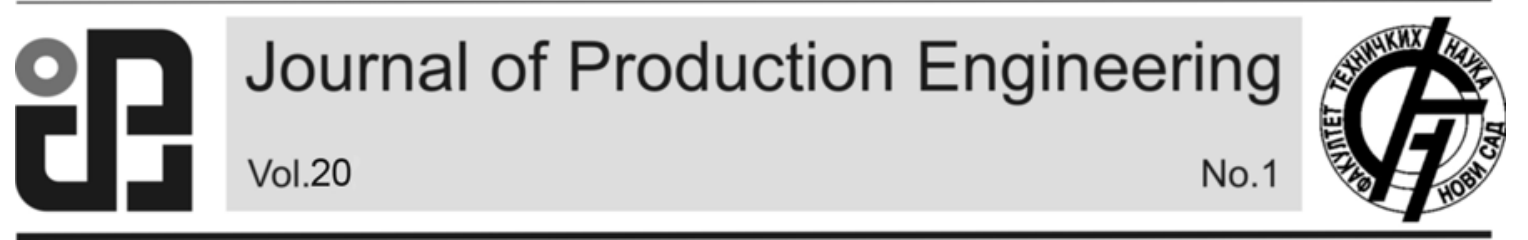

JPE (2017) Vol.20 (1)

Singh, $\mathbf{B}$.

Original Scientific Paper

\title{
THE CORRELATION OF WELD MICROSTRUCTURE AND PROPERTIES WITH ELEMENT TRANSFER IN SAW WELDS
}

Received: 07 March 2017 / Accepted: 19 April 2017

\begin{abstract}
This study explores the effect of various elements transfer to the welds on its microstructure and properties. The fluxes were designed using RSM and were made by agglomeration technique. This study reveals that the pearlite or ferrite formation in the welds depends upon the flux constituents. The carbon, manganese, oxygen and nickel transfer have been correlated with the pearlite formation in the welds. The welds dilution also shows a significant effect on weld properties.
\end{abstract}

Key words: $S A W$, dilution, weld oxygen, pearlite, ferrite

Korelacija mikrostrukture šava i osobine elementa u SAW varovima. Ova studija istražuje uticaj prelaza različitih elemenata u zavaru na njihova mikro svojstava. Prelazi su dizajnirani korišćenjem RSM $i$ rađeni su tehnikom aglomeracije. Ova studija otkriva da formacija perlita ili ferita u zavaru zavisi od fluksa sastojaka. Prelaz ugljenika, mangana, kiseonika i nikla su u korelaciji sa formiranjem perlita u zavarima. Razblaživanje zavarenih spojeva takođe pokazuje značajan efekat na svojstva zavara.

Ključne reči: $S A W$, razređivanje, kiseonik za zavarivanje, perlit, ferit

\section{INTRODUCTION}

Submerged arc welding is also known as hidden arc welding was developed for making high quality butt welds in thicker plates. The arc is produced from the end of a continuous electrode which is buried under the thick layer of flux. The heat of the arc causes the melting of electrode, base plate and the adjacent flux. The lower layer of the flux is melted and reacts with the impurities and forms a slag while the upper unused layer is collected by a hopper and it is again used. It gives the double protection against the atmospheric contamination [1]. In recent years fully automatic and semiautomatic SAW equipments have resulted in an increase in welding speed and their use has made possible to obtain high quality joints. The electrodes used for SAW are either bare or copper coated to prevent them from corrosion. The coating also increases the electrical conductivity of the electrode wire. For welding of various types of steels various combinations of electrodes and fluxes are in use. Fluxes are the chemical substances that are used as a cleaning agent in welding. The SAW fluxes contain lime, silica, manganese oxide, calcium fluoride and other compounds. In SAW the weld pool is protected from the atmospheric contamination by being submerged under a blanket of granular fusible flux. In the molten state, the flux becomes conductive and provides a current path between the electrode and work piece. Fluxes can be categorized depending upon the method of manufacture, the extent to which they can affect the alloy content of the weld deposit and the effect on weld deposit properties.

The basic functions of the fluxes in SAW are to improve arc stability, to refine the weld metal and to add the alloying elements [2-3].The various ingredients of flux decides the weld composition and properties. The physical and chemical properties of flux and welding process parameters decide the transfer of various elements to the weld.

The mechanical properties of the weldments depend upon the microstructure developed during submerged arc welding [4]. The microstructure of a weld metal in turn largely depends on the heating and cooling cycle. The microstructure is also affected by the welding process, process parameters and the material to be welded. The important factors that decide the microstructure are chemical composition of the weld, heating and cooling rate and flux composition used for welding. The weld oxygen content and the shape and size of inclusions also have a definite effect on microstructure [5].

The heat input and cooling rate both have a direct effect on the microstructure of final weld metal composition [6-7]. The austenite - ferrite transformation, cooling rate and different ferrite morphologies are important considerations for improving the mechanical properties. The various microstructures formed in low carbon steel welds are grain boundary ferrite, widmanstatten ferrite, side plate ferrite and micro phases (A small amount of martensite, retained austenite or degenerated pearlite) depending on the cooling rate and composition. Dallam et al. [8] studied the microstructure of low carbon steel weld and HAZ and observed various subzone microstructures in HAZ such as spheroidized zone, partially transformed zone, grain refined zone and grain coarsened zone. The same has been verified by the various other researchers [8-10]. The weld metal microstructure is controlled mainly by cooling cycle while the metallurgical transformations in HAZ are related to both heating and cooling cycle [11-12]. The various microstructures 
obtained in welds of low carbon steel are widmanstatten ferrite, acicular ferrite, pearlite, grain boundary ferrite, bannite and polygonal ferrite. Following microstructures are obtained in the weld of low carbon steels.

Weld microstructure is affected by the weld oxygen content [13-15]. For formation of acicular ferrite an optimum level of oxygen is required. The acicular ferrite is also increased with increase of $\mathrm{Al}$ content in the weld up to a certain limit. If it is increased beyond a certain limit the formation of acicular ferrite is reduced. Jordar et al.[16] have reported that the pro-eutectoid ferrite was obtained when the size of inclusions were lying between $(0.2-0.7) \mu \mathrm{m}$, while acicular ferrite was formed when the size of the inclusions were larger.

Various contents like Calcium and $\mathrm{Mg}$ are insoluble in steel while $\mathrm{Al}, \mathrm{Mn}, \mathrm{Si}$, and $\mathrm{Ti}$ contents are soluble in steel. These can react with the sulphur and oxygen present in the weld and may form sulphide or oxide inclusions. Sulphur may be present as an impurity in the flux or base metal and it is usually found in those inclusions which may have Mn content. In the same way $\mathrm{Al}$ content may be present in the flux or base plate or wire, which may change the inclusion population and finally the microstructure of the weld metal. Aluminum reacts with weld oxygen and forms aluminum oxide. This is given in equation (1).

$$
2 \mathrm{Al}^{3+}+3 \mathrm{O}^{2-} \rightarrow \mathrm{A}_{2} \mathrm{O}_{3}
$$

These inclusions may be present in the form of alumino silicates, aluminates and mixed oxides. In the same way silicon and titanium are soluble in steel and easily reacts with oxygen in the weld to form dioxides but these oxides further reacts with oxygen and give reactive positive ions and negative ions. These cations or anions react with elements present in the weld pool. The silicon ions react with oxygen to form silicates as shown in equations (2) and (3).

$$
\begin{aligned}
& \mathrm{Si}^{4+}+\mathrm{O}^{2-} \rightarrow \mathrm{SiO}^{2+} \\
& \mathrm{SiO}_{2}^{2+}+3 \mathrm{O}^{2-} \rightarrow \mathrm{SiO}_{4}{ }^{4-}
\end{aligned}
$$

Silicon may be present in the inclusion in the form of manganese silicates, manganese alumino silcates etc. Thus sulphur and oxygen both are mainly responsible for inclusion formation. These inclusions also affect the mechanical properties.Besides the element transfer oxygen affects the volume fraction, type and size of inclusions which finally may decide the toughness and strength of the welds. The Tables 1-4 represent the design matrix, factors and their levels, wire and plate composition and welding parameters respectively.

\section{EXPERIMENTAL PROCEDURE}

1. Twenty fluxes were designed as per RSM by using central composite design. The designed matrix in the coded form is given in Table 1. The three factors, wire and plate composition are given in Table 2 and 3 respectively. While, the welding parameters are shown in Table 4.

2. The base fluxes $\mathrm{CaO}, \mathrm{SiO}_{2}$ and $\mathrm{Al}_{2} \mathrm{O}_{3}$ were selected and mixed in the ratio of 7:10:2 as per binary and ternary phase diagrams. The additives $\mathrm{CaF}_{2}, \mathrm{FeMn}$ and $\mathrm{NiO}$ were added in the range of $(2-8) \%$.

3 . Twenty fluxes were prepared by agglomeration technique.

4. Beads on plate welds were made on $18 \mathrm{~mm}$ thick MS plates of the given composition. Welding parameters such as voltage, current and travel speed were kept constant. These parameters are given in Table 4

5. In this study $10 \%$ dilution effect of the base plate has been assumed.

6. Chemical analysis of the bead was done from the powder, extracted from the top bead with the help of a drill. The measured responses are given in Table 5 .

7. The transfer of manganese was calculated by a $\Delta$ Delta quantity $=$ Analyzed composition - Expected composition.

The expected composition was calculated from the below given relation:

dilution $\times$ base plate composition + $(100-$ dilution $) \times$ wire composition

\begin{tabular}{|c|c|c|c|}
\hline $\begin{array}{l}\text { No. of } \\
\text { Exp. }\end{array}$ & $\begin{array}{l}\mathrm{CaF}_{2} \\
\text { wt } \% \mathrm{~A}\end{array}$ & $\begin{array}{l}\text { FeMn } \\
w t \% \text { B }\end{array}$ & $\begin{array}{l}\mathrm{NiO} \\
\text { wt \% C }\end{array}$ \\
\hline 1 & +1 & -1 & -1 \\
\hline 2 & 0 & +1 & 0 \\
\hline 3 & +1 & -1 & +1 \\
\hline 4 & -1 & -1 & -1 \\
\hline 5 & 0 & 0 & 0 \\
\hline 6 & 0 & 0 & 0 \\
\hline 7 & +1 & +1 & +1 \\
\hline 8 & 0 & 0 & 0 \\
\hline 9 & 0 & -1 & 0 \\
\hline 10 & +1 & 0 & 0 \\
\hline 11 & 0 & 0 & +1 \\
\hline 12 & -1 & -1 & +1 \\
\hline 13 & 0 & 0 & 0 \\
\hline 14 & 0 & 0 & 0 \\
\hline 15 & +1 & +1 & -1 \\
\hline 16 & -1 & 0 & 0 \\
\hline 17 & 0 & 0 & 0 \\
\hline 18 & 0 & 0 & -1 \\
\hline 19 & -1 & +1 & +1 \\
\hline 20 & -1 & +1 & -1 \\
\hline
\end{tabular}
100

Table 1. Design matrix in coded form.

\section{CORRELATIONS OF MICROSTRUCTURE WITH ELEMENT TRANSFER}

With an increase of $\mathrm{C}, \mathrm{Mn}$ and $\mathrm{Ni}$ contents to the welds, the pearlite percentage of the microstructure is reduced. This has been depicted in the Figures 1-3 respectively. These figures show that the element transfer has a significant effect on the microstructure of the weld. With the increase of carbon proportion, the pearlite content is reduced although it is assumed that with increase of carbon content in the weld, the pearlite content increases in carbon steels [17]. This is shown in 
the Figure 1.This may be dueto very low carbon present in the welds and also dueto reduction in impact strength with increasing weld carbon. In this study it has been verified that the impact strength increases with increase of pearlite content in the welds. As with the increase of carbon content, the impact strength is reduced so, the pearlite content might also be reduced. Weld Mn content also reduces the pearlite content. This has been given in Figure 2. It may be attributed to its nature of increasing hardness and promoting ferrite formation [18]. The increase of weld Mn content increases the hardness and consequently, the reduction in impact strength [19] and [20]. So the pearlite content might also be low. The same type of variation is also observed for Ni content. This is shown in the Figure 3. Although, the impact strength of the welds increase with increase of $\mathrm{Ni}$ content to a certain extent but the pearlite content is reduced.The pearlite content is high in both the cases when the weld oxygen is either very low or very large. This has been depicted in Figure 4. The weld oxygen has a definite effect on microstructure of the welds [21] and [22]. The BI also affects the various elements transfer to the weld.

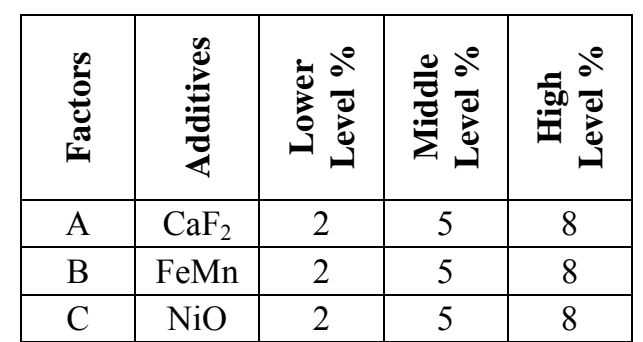

Table 2. The three factors and their levels.

\begin{tabular}{|l|c|c|}
\hline Composition & Base Plate & Wire \\
\hline Carbon \% & .03 & .11 \\
\hline Silicon \% & .07 & .09 \\
\hline Manganese \% & .34 & .45 \\
\hline Sulphur \% & .017 & .021 \\
\hline Phosphorus \% & .022 & .021 \\
\hline Nickel \% & - & - \\
\hline
\end{tabular}

Table 3. The wire and plate composition

\begin{tabular}{|c|c|c|c|}
\hline S.No. & Voltage & Current & Travel speed \\
\hline 1 & 30 volts & 475 ampere & $20 \mathrm{~cm} /$ minute. \\
\hline
\end{tabular}

Table 4. The Welding parameters

\begin{tabular}{|c|c|c|c|c|c|c|c|c|}
\hline $\begin{array}{c}\text { Flux } \\
\text { NO }\end{array}$ & $\begin{array}{c}\text { Weld } \\
\text { C\% }\end{array}$ & Mn \% & Ni \% & $\begin{array}{c}\text { UTS } \\
\text { MPa }\end{array}$ & $\begin{array}{c}\text { Impact } \\
\text { Strength }\end{array}$ & $\Delta$ Mn & $\begin{array}{c}\text { Weld } \\
\text { dilution \% }\end{array}$ & BI \\
\hline 1 & 0.03 & 0.17 & 0.177 & 270 & 58 & -0.267 & 0.387 & 0.839 \\
\hline 2 & 0.03 & 0.37 & 0.702 & 318 & 55 & -0.069 & 0.179 & 0.847 \\
\hline 3 & 0.04 & 0.23 & 0.544 & 320.2 & 64 & -0.209 & 0.454 & 0.973 \\
\hline 4 & 0.04 & 0.17 & 0.374 & 189.8 & 20 & -0.269 & 0.366 & 0.710 \\
\hline 5 & 0.04 & 0.35 & 0.388 & 300 & 12 & -0.089 & 0.467 & 0.840 \\
\hline 6 & 0.08 & 0.31 & 0.25 & 320 & 14 & -0.129 & 0.281 & 0.840 \\
\hline 7 & 0.04 & 0.38 & 0.477 & 190.7 & 56 & -0.059 & 0.257 & 1.00 \\
\hline 8 & 0.08 & 0.34 & 0.27 & 284.7 & 23 & -0.099 & 0.555 & 0.840 \\
\hline 9 & 0.03 & 0.34 & 0.474 & 280.1 & 60 & -0.099 & 0.399 & 0.832 \\
\hline 10 & 0.04 & 0.42 & 0.744 & 292.6 & 46 & -0.019 & 0.388 & 0.910 \\
\hline 11 & 0.04 & 0.15 & 1.33 & 240 & 12 & -0.289 & 0.251 & 0.910 \\
\hline 12 & 0.03 & 0.57 & 0.44 & 175.7 & 14 & 0.131 & 0.357 & 0.832 \\
\hline 13 & 0.07 & 0.38 & 0.32 & 330.9 & 14 & -0.059 & 0.473 & 0.840 \\
\hline 14 & 0.04 & 0.39 & 0.32 & 326.5 & 40 & -0.049 & 0.411 & 0.840 \\
\hline 15 & 0.04 & 0.24 & 0.054 & 351 & 56 & -0.199 & 0.388 & 0.847 \\
\hline 16 & 0.04 & 0.25 & 0.344 & 152.3 & 36 & -0.189 & 0.396 & 0.773 \\
\hline 17 & 0.03 & 0.50 & 0.452 & 319.5 & 14 & 0.061 & 0.482 & 0.840 \\
\hline 18 & 0.04 & 0.29 & 0.366 & 351 & 12 & -0.149 & 0.405 & 0.773 \\
\hline 19 & 0.04 & 0.33 & 0.502 & 128.8 & 58 & -0.109 & 0.454 & 0.847 \\
\hline 20 & 0.04 & 0.33 & 0.288 & 319.5 & 60 & -0.109 & 0.566 & 0.714 \\
\hline
\end{tabular}

Table 5. Measured Responses

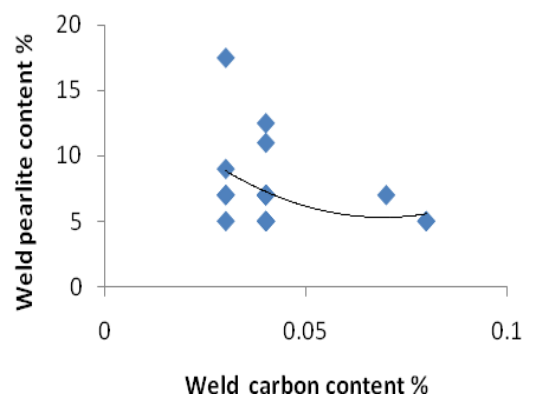

Fig. 1. Correlation of pearlite content with carbon proportion

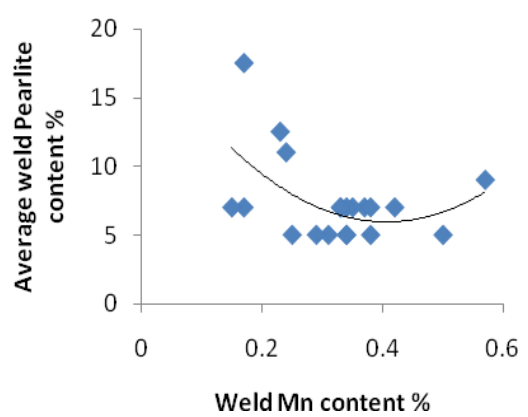

Fig. 2. Correlation of pearlite content with weld Mn content. 


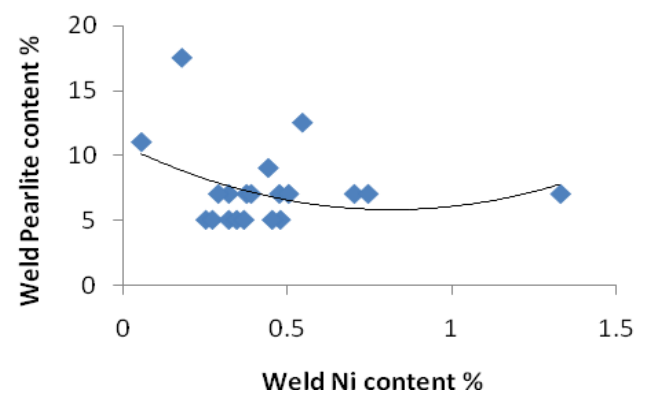

Fig. 3. Correlation of pearlite content with weld $\mathrm{Ni}$ proportion

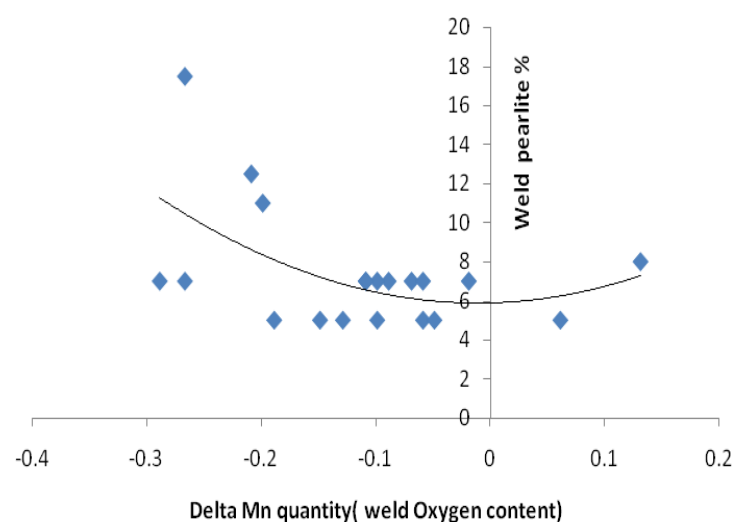

Fig. 4. Effect of weld Oxygen on pearlite content.

\section{CONCLUSIONS}

1. The correlation of $\mathrm{C}$ and $\mathrm{Ni}$ transfers show that the pearlite content is reduced with increase of these elements.

2. The weld pearlite after an initial decrease, it increases with increasing weld Mn comtent.

3. The pearlite content is high in either case when the weld oxygen is either very high or very low.

4. The element transfer to the weld has a definite correlation with the weld microstricture.

\section{REFERENCES}

[1] Hould Croft, P.T., (1989) Submerged arc welding Second Ed. Abington publishing, Cambridge, England.

[2] Linert, G., (1995) Weld. Metallurgy, American welding society, New York.

[3] Jackson, C.E., (1960) The science of arc welding part-1 Definition of arc. Welding Journal 30: 129140.

[4] Jordar, A., Saha, S.C., Ghosh, A.K., (1991) Study of submerged arc weld metal and HAZ microstructure of plain carbon steel welding. Welding research supplement: 141-147.

[5] Jang, J.W., Shah, S., and Indacochea, J.E., (1987) Influence of SAW fluxes on low carbon steel weld microstructure. J. Materials for Energy systems, 8(4): 391-400.

[6] Easterling, K.E., (1992) Introduction to physical metallurgy of welding. Butter worth-Heinemann.

[7] Svensson, L.E., (1994) Control of microstructure and properties in steel arc welding, CRC press, Boca Raton, FL: 101-106.

[8] Dallam, C.B., Liu, S., Olson, D.L., (1985) Flux composition dependence of microstructure and toughness of submerged arc HSLA weldments. Welding journal, 64(5): 140-151.

[9] Kou, S., (1987) Welding metallurgy, Wiley International Publisher, New York: 66-75.

[10] Rasanen, E., and Tenkula, J., (1972) Phase changes in the welded joints of construction steels. Scandivian Journal of metallurgy, 1:75-80.

[11] Cornu, J., (1988) Advanced welding systems part 2. IFS Publication Ltd, London: 97-123.

[12]Dolby, R.E, (1983) Advances in welding metallurgy of steels. Metals Technology, 10(9): 349-362.

[13] Abson, D.J., Dolby, R.E., Hartn, P.H., (1978) The role of non-metallic inclusions in ferrite nucleation in carbon steel weld metals. Proc. Intl. Conf. on trends in steels and consumables for welding, London, England, The welding institute, ibid: 75-101.

[14] Abson, D.J., Dolby, R.E., (1978) Microstructural transformation in steel weld metal- A Reappraisal. Welding Institute research bulletin: 202-206.

[15] Cochrane, R.C., Kirkwood, P.R., (1978) The effect of oxygen on weld metal microstructure Trends in steel and consumables for welding. The welding Institute, London, Paper 35: 103-121.

[16] Jordar, A., Saha, S.C., Ghosh, A.K., (1991) Study of submerged arc weld metal and HAZ microstructure of plain carbon steel welding. Welding research supplement: 141-147.

[17] Heuschkel J. weld metal composition control.Welding J. 1963;48(8):323-347

[18] Gonzaga RA, Martenz L,P, Perez A , Villanueva P. Mechanical properties dependency of the pearlite content of ductile iron.Journal of Achievements in Materials and Manufacturing Engg. 2009; 33(2):150-158.

[19] Heuschekel,J. Weld metal property control. Welding J.1973; 52(1):1-20.

[20] Abson DJ, Dolby RE, Hartn PH. The role of nonmetallic inclusions in ferrite nucleation in carbon steel weldmetals. Proc. Intl. Conf .on trends in steels and consumables for welding, London, England, The welding institute, ibid, 1978; : 75-101.

[21]LIU S, Olson DL. The role of inclusions in controlling HSLA steel weld microstructure. Welding journal, 1986; 65(6):139-149.

[22] Sammy-Armstrong Atta-Aayemang. Optimization of strength and toughness on the effect of the weldable HSS used in offshore structures. Master of science thesis Lappeenavanta University of Technology 2013.

Authors: Dr Brijpal Singh, A.P Mech Engg. Department, Maharaja Surajmal Institute Of Technology, C-4 Janakpuri, New Delhi, India 110059 Email : brijpalsingh101@gmail.com 